\title{
College English Teaching Reform in the New Media Era
}

\section{Weiwei Qu}

Teaching and Research Institute of Foreign Languages, Bohai University, Jinzhou, 121013, China

syquwei@yeah.net

Keywords: New media era; college English; teaching reform; reform contents

\begin{abstract}
The college English teaching under the new media environment has effectively made up for the defects of the traditional classroom teaching, and provided convenience for college English teaching. To study this paper in order to improve the level of college English teaching and meet the teaching requirements of the new media era which analyzes the characteristics of the new media, the problems existing in the traditional college English teaching, and puts forward the contents of the teaching reform of college English in the new media era. The specific contents hereby are including actively use of new media environment, the use of new media technologies to strengthen education, promotion of micro video applications in English teaching, to expand the reading quantity through the network media platform, to achieve the combination of personalized teaching, English teaching and new media resources.
\end{abstract}

\section{Introduction}

Compared to traditional media, new media is a new shape developed after newspapers, radio and television, and also a communication form or media shape use of digital technology, network technology, mobile technology providing information and entertainment to users through the Internet, wireless communication network and cable network channels and computer, hand machine, digital television and other terminals. The development of the media has experienced the stage of elite media, mass media and personal media, which represent the agricultural, industrial and information times. In the rapid development of the Internet today, the new media has moved from the edge to the mainstream. The radio is a new media relative to the newspaper, television is a new media relative to the network, the network is a new media relative to television. With the development of science and technology and the development of media, we can see that the new media is changing with the development of media.

College English is a course which is closely related to the theoretical knowledge and practical skills, and the skills of listening, speaking, reading, writing and translating are one of the essential qualities of College students. In recent years, a variety of new media resources and the rapid development of Internet technology provide favorable conditions for the teaching reform of English. The new media has changed the traditional teaching method on teaching materials, with expressive elements of modern science and technology into classroom teaching, bring students multi sensory experience pleasure which stimulate interest in learning and initiative; the new media expands the knowledge of English information storage capacity. In addition to classroom teaching, students also can use the spare time new media tools and platform for autonomous learning; The use of new media to assist teaching can achieve multi interactive, so that the classroom teaching are more dynamic, more convenient and efficient communication between teachers and students [1,2]. In the new media environment, the new mode of information dissemination and communication are always occurring. The use of new media resources in college English teaching, overcomes the drawbacks of traditional teaching mode, and constantly improve the quality of teaching.

\section{Characteristics of New Media}

The characteristics of new media are convenience and integration, interactivity and immediacy, mass and sharing, multimedia and hypertext, personalization and socialization.

(1) Convenience and integration [3]. Access to information and browsing information is 
particularly convenient and quick, and hence changing people's way of life and rhythm. We can know everything at home, access to our interested topics and news articles, etc. by moving our fingertips , we can also learn the knowledge the traditional classroom teaching cannot be touched by. It refers to the scattered information, including voice, text, images and video to re-integration, so that information is more accurate, vivid, vivid and complete.

(2) Interactivity and immediacy. The way of transmission of traditional media is one-way, linear and optional. The way of the new media communication is two-way, the traditional publishers and audiences have become the publisher of information, and can interact. The interaction of information also makes the audience realize the change from passive to active. With the development of technology, the new media can be transmitted in real time, and the technology is simple and convenient. This advantage is unmatched by any traditional media.

(3) Mass and sharing. Mass of characteristics can be understood from the following aspects, the network communication to achieve a global coverage; network communication to achieve the mass storage of information; network dissemination of information storage in the quality of diversity. The Internet connects computers and computers all over the world, creating a huge database. The spread of traditional media is often limited to local, but network communication is not subject to geographical restrictions, in any corner of the world, as long as you have access to information on the internet.

(4) Multimedia and hypertext. Network communication achieves the "multimedia communication means of text, sound, images and animation" and a variety of combination, to maximize the spread of various forms of "enrich the means of communication, absorb anything and everything". The text of the hypertext composing mode and structure of communication links, making the information retrieval to the time and space of all-round opening up, easily realized the query function of "now and then, here or there," or "same or different" and "synchronous or asynchronous".

(5) Personalization and socialization. Personal characteristics of network communication technology advantage is very obvious, so the audience can easily use a variety of retrieval tools in various databases for "each one takes what he needs". "Information push technology" can also provide specialized services to push information according to user needs. Network community is equivalent to provide a free virtual communication space, so that people with common needs can be very convenient and no time difference to have the space for discussion and free information space.

\section{Existing Problems in Traditional College English Teaching}

There are some problems in college English teaching, which hinder the improvement of the quality of college English teaching. It is not good for students to improve their English application ability and comprehensive quality. The problems are mainly manifested in five aspects [4-6]:

(1) Single teaching purpose. For a long time, the examination oriented education pays attention to the students' ability to answer questions, and ignores the comprehensive abilities of "listening, speaking, reading, writing and translating." Teachers pay attention to the understanding of the content of the text. Students in the classroom is difficult to improve the ability to use English. Teachers systemly explain the words, grammar and sentence patterns so that lack of vitality in the classroom atmosphere. Teachers teach English as a language knowledge, did not realize that it is an application of language skills. The teaching methods are improper;

(2) Rigid teaching mode. College English is a public class in university. As there are many students, it is difficult for teachers according to the characteristics of students targeted to explain. Many teachers tend to cramming teaching mode, lectures on the podium in the text, few organizations related to teaching activities in the classroom. This model is difficult to stimulate students' interest in learning English, can not effectively achieve the desired teaching objectives. It is leading to the mechanization of teaching process, the single teaching means, the neglect of students' language skills and so on;

(3) The limitation of classroom teaching resources. The richness of new media learning resources highlights the limitation of traditional college English teaching resources. The traditional 
college English teaching use of paper materials, although the teachers use the multimedia technology in the teaching, such as PPT, audio and video, but the classroom is still around to teaching as the center of knowledge and teaching. English classroom teaching is boring and some students do not lead to love English.

(4) Study time and space passivity. The traditional form of classroom teaching determines the autonomy of learning and accepting knowledge. Students rely on teachers to teach, there is no more independent choice of learning content, learning methods and learning opportunities. Different students have different ability to comprehend the same knowledge. In self digestion and absorption of teaching content after class, they can not reproduce the classroom teaching situation, and can not carry on the two study to the teaching content. The individual differences of students are not taken seriously, which limits the subjective initiative and creativity of learning, and directly affects the learning effect.

(5) The focus of teaching is inclined, "teaching", "learning" and "using" are out of touch. For college English teaching, two times a year the four grade and six grade national examination is a severe test. It is lead to many teachers refer four and six examinations as a baton, focusing on training students' ability to test. They often use the sea tactical, research examination skills, ignored practical skills training of English, causing most students lack of independent personality and spirit, the purpose of teaching cannot be implement better.

\section{Reform Contents on College English Teaching in the New Media Era}

According to the characteristics of the new media and the problems existing in the traditional college English teaching, this paper puts forward the reform contents of college English teaching in the new media era, which is related to [7-11]:

(1) Actively promote the use of new media environment. Although many English teachers have realized the importance of new media, but in the mining of new media function is not comprehensive, just to write some data tables, text and courseware making use of new media technology, few to use other software applications. Teachers in the classroom should learn how to use the new media environment and technology, save class time, improve classroom efficiency, leave more time for students to create and play. Teachers also need to actively grasp and make good use of new media, to create conditions for students' innovative activities, including mobile phone, camera, etc. all these need VideoStudio software, which can keep pace with the times and lifelong learning. For students, we should learn how to use new media to learn English and practice innovation. Now many universities of the modern advanced equipment are complete, students can use the school existing network learning platform to learn English, through the mobile phone Internet and other means for innovation activities and communicate with others in English.

(2) Using new media technology to strengthen the education of listening and speaking. Listening and speaking are important parts of English teaching, and they are also difficult points in English learning. In the teaching of listening and speaking, they can use new media technology to provide more materials for listening training, to provide a platform for oral practice. In the teaching of listening, through new media technology and new media platform, helping the students to accumulate the listening material, which can be collected from the network media. In the English classroom English playing songs and movies, let the students listening in watching movies or listening to songs, so as to cultivate language sense. You can also collect some English news, to strengthen the introduction of a variety of cultural backgrounds. Teachers can explain the western culture and news background and other related knowledge. In oral English teaching, teachers should provide more training opportunities, use the new media platform and a variety of software, to provide the real context, make students imitate. Communication skills can also be used to communicate with foreign friends, correct pronunciation in dialogue practice, achieve the goal of fluent dialogue.

(3) The application of micro video in English teaching. In the new media environment, provides the best interactive media for the innovation of English teaching, the teaching material innovation provides the best integration of online media for English teaching, while the micro video English 
teaching provides a full range of innovative experience field. Due to the length of time the micro video is not restricted, and the production threshold is low, students can use handheld terminal with video recording function, based on any scene of skits in English or English video creative production. Using the full range of English language, is the convenience brought by high-tech, also provided simply learning the language to use knowledge for students, and carries on the processing, playing and creating. Compared with other English teaching methods, micro video not only provides students with the experience of applying English language, but also provides an opportunity to improve the level of information technology.

(4) Through the network media platform to expand the amount of reading. The unique human novelty and difference of psychological needs, determines the news strong demand, urgency and consistency of the network media to meet the human needs of news. Students love reading English newspapers knows, the English newspapers they get in hand are already a few days ago, the newspaper published the news has become the "news", lose effectiveness, and type of newspaper is very limited. Online media can enable students to log on to the English national newspaper website, browse the news of the day, you can also browse the previous content. Through the network media platform to establish hyperlinks or unified authentication, so that students can easily access to the relevant website. In the practice of college English teaching, Internet communication is favored by teachers and students. Through the network media platform, curriculum counseling, Q\&A, discussion, submission and return operations, between teachers and students, between teachers and teachers and between students and students all can be achieved. Teachers can also guide the students in different places to carry out teaching practice and thesis writing.

(5) Realize personalized teaching. Individualized teaching is to respect students' individuality teaching according to students' personality, interests, strengths and needs of teaching, what students need, what teachers teach, students is a kind of autonomous learning. Individualized teaching enables students to have more opportunities for independent thinking and practice, improve their quality and develop their potential, and promote the all-round development. Rich new media resources to provide free choice learning space, through the excellent course construction, the construction of campus network and air classroom form, will recommend outstanding new media resources to students, will recommend different new media resources to different learning levels of students. Students according to their own actual situation to choose their own way of learning and learning content, and to make an assessment of learning. College English teaching can fully take into account the individual differences of learners, personalized teaching, improve students' participation, cultivate self-study ability, to achieve the goal of teaching reform for teachers and students as the main body of the leading.

(6) The combination of English teaching materials and new media resources. English textbooks are the most important curriculum resources for students to learn English, while the new media can provide a wealth of learning resources, therefore, English teachers should combine the two. College English teaching material is the result of long-term research and careful screening by experts. It has a strong readability, and has a positive role in promoting college students' English learning ability and level. However, compared with the simple paper textbooks, new media resources is abundant, because new media can bring fresh instant information from many aspects such as audio-visual, can see the flexible use of English in daily life, more attractive to students. In practice, English teachers should be teaching content and new media resources combined, give full play to the advantages of each of the two, based on the teaching content, combined with the latest information provided by the new media, through a variety of ways to attract students to participate in the discussion topic of interest, change the textbooks single lag shortcomings, will make the whole teaching content and rich, and good teaching effect.

\section{Conclusion}

English teaching and new media means the combination of the English teaching presents many new features, approach for students to acquire the variety of information resources, learning can break the constraints of time, teaching content is more rich. To better adapt to college English teaching, 
improve teaching efficiency, promote English teaching of the rich, vivid and interesting, to better enhance the learning interest of the students, we must reasonably use the new media aided teaching method [12]. The college English Teaching under the new media environment has effectively made up for the defects of the traditional classroom teaching, and provided convenience for College English teaching. But in the concrete teaching process, there are also some problems, including: the selected knowledge confined to to solve the "problem" for the driver, the new media technology popularization and application, teaching management costs rising rapidly and teaching assessment. The new media technology in classroom teaching to bring development opportunities, but also bring new challenges to the teachers teaching level at the same time, which requirements of teaching content and teaching method of teachers should be adjusted accordingly. The results of this study, points out the practical scheme for the reform of college English teaching in the new media era, helps to improve the quality of English teaching, enrich the classroom inside and outside of the means of education, cultivate compound English telents with extensive knowledge, strong thinking ability and innovation consciousness.

\section{Acknowledgement}

This work is supported by 2015 Cooperative project of allied social science association of Liaoning province and allied social science association of university (lslgslhl-025): Research on Construction and Practice for Cooperative College English Writing Teaching Mode based on Automatic Evaluation System.

\section{References}

[1] X. Li, "The application of new media resources in college English teaching," News Research, vol. 29, no. 1, pp. 107-108, 2012.

[2] Y. M. Mu, "The advantages and Strategies of new media in college English teaching," China Newspaper Industry, vol. 29, no. 4, pp. 34-35 2016.

[3] G. Y. Guan, Y. F. Ma, "The opportunities and challenges of college English teaching from the perspective of new media," English Square (Academic Research), vol. 4, no. 3, pp. 116-117, 2014.

[4] Lotus Mountain courseware, "On the problems and countermeasures in college English teaching," http://www.5ykj.com/Article/jxlwyylw/31543.htm, 2017-1-10.

[5] F. Fan, "Opportunities and challenges of college English teaching model innovation under the new media," Sun Yatsen University Forum, vol. 27, no. 10, pp. 264-267, 2007.

[6] X. Z. Chen, "College English teaching in the new media era," Journal of Fujian Medical University (Social Science Edition), vol. 15, no. 4, pp. 57-60, 2014.

[7] Y. Y. Yin, X. Y. Tong, "On the Application of New Media in English Teaching to Students of Science and Technology Universities: Taking the Universities in Zhejiang Province as an Example," Research in Higher Education of Engineering, vol. 34, no. 5, pp. 141-145, 2016.

[8] Z. Y. Meng, H. B. Zhuang, "Actively respond to the impact of new media on college English teaching," Academic Journal of Shanxi Provincial Committee Party School of C.P.C, vol. 36, no. 4, pp. 127-129, 2013.

[9] Lin. Yang, "College English teaching reform and innovation under the new media environment," Overseas English, vol. 17, no. 18, pp. 46-47, 2016.

[10] N. Zhang, "The application of new media in college English teaching reform," Journal of Yan'an Vocational \& Technical Institute, vol. 29, no. 6, pp. 69-70, 2015.

[11] F. Jiang, "The evolution relationship," The application of new media resources in college English teaching, China Newspaper Industry, vol. 29, no. 6, pp. 93-94, 2016.

[12] D. D. Xu, "Research on college English teaching reform under the new media environment," Social Sciences in Guangxi, vol. 29, no. 5, pp. 214-216 2016. 